\title{
Trophic structure of coastal freshwater stream fishes from an Atlantic rainforest: evidence of the importance of protected and forest-covered areas to fish diet
}

\author{
Cristina da Silva Gonçalves • \\ Francisco Manoel de Souza Braga • Lilian Casatti
}

Received: 2 March 2017 / Accepted: 9 March 2018 / Published online: 19 March 2018

(C) Springer Science+Business Media B.V., part of Springer Nature 2018

\begin{abstract}
The role of riparian forests in the functioning of aquatic ecosystems is well known, and they are recognized as an important food source for riverine fauna. This study investigates the trophic structure of coastal freshwater stream fishes from a large conservation area in an Atlantic rainforest using stomach content and food availability analyses. Four samples were collected from 19 sample sites. Fishes were caught with electrofishing. Prey were sampled with trays, Surber, traps, and electrofishing to evaluate the availability of food resources. The diets of 20 fish species were determined from the stomach contents of 1691 individuals. Terrestrial and aquatic insects and detritus were the most consumed items. Fish diet and prey availability were not seasonally dependent. A cluster analysis showed five trophic functional groups: terrestrial insectivores,
\end{abstract}

C. da Silva Gonçalves $(\bowtie) \cdot$ F. M. de Souza Braga

Departamento de Zoologia, Universidade Estadual Paulista "Júlio de Mesquita Filho" (UNESP), Instituto de Biociências (IB),

Avenida 24-A, 1515. Bela Vista, CEP 13506-900, Rio Claro, São Paulo, Brazil

e-mail: cristina.silva.goncalves@gmail.com

F. M. de Souza Braga

e-mail: fmsbraga@rc.unesp.br

L. Casatti

Departamento de Zoologia e Botânica, Laboratório de Ictiologia, Universidade Estadual Paulista "Júlio de Mesquita Filho"

(UNESP), Instituto de Biociências, Letras e Ciências Exatas (IBILCE), Rua Cristóvão Colombo, 2265, Jardim Nazareth, CEP 15054-000, São José do Rio Preto, São Paulo, Brazil

e-mail: licasatti@gmail.com aquatic insectivores, detritivores, carnivores, and omnivores. Insectivores predominated in species richness $(60 \%)$, abundance (47\%) and biomass (39\%). Allochthonous and autochthonous items were found in similar proportions in the environment; however, allochthonous items were representative for insectivores and detritivores, whereas autochthonous items were important for primarily aquatic insectivores. The preference for certain insects by insectivorous fishes was associated with food selectivity rather than the availability of the resource and demonstrated the strong relationship between feeding behavior and food preference. The absence of seasonal variation in the diets of the fishes was possibly related to the consistent food supply. Our results confirm the role of the forest as a food provider for stream fishes, such as terrestrial insects and plant debris/ detritus (also consumed by aquatic insects, which subsequently serve as food for fish), highlighting the importance of conserving the Brazilian Atlantic rainforests.

Keywords Juréia-Itatins · Riparian forest - Terrestrialaquatic linkage $\cdot$ Food resource availability $\cdot$ Food preference $\cdot$ Macroinvertebrates $\cdot$ Aquatic insects

\section{Introduction}

The importance of forested areas in maintaining the function of aquatic ecosystems is well documented, and numerous functions are recognized (Gregory et al. 1991; Osborne and Kovacic 1993; Naiman and 
Décamps 1997; Pusey and Arthington 2003). Riparian forests are transition zones between terrestrial and aquatic ecosystems and therefore act in several processes involving the transfer of energy and matter (inorganic and organic) (Pusey and Arthington 2003): they regulate the temperature and the primary aquatic production through shading (Kiffney et al. 2003), they maintain structural characteristics and increase channel stability due to sediment entry control (Lorion and Kennedy 2009b), and they mediate the input and processing of nutrients and organic matter (Cummins 1974; Gregory et al. 1991).

Riparian forests also represent an important food source for fish (Nakano et al. 1999) and macroinvertebrates (Anderson and Sedell 1979). The trunks, branches, leaves, fruits, seeds and invertebrates from the forest are important sources of nutrients for these organisms. Trunks, branches and leaves increase the structural complexity of a stream, serve as refuge (e.g., from predation and stream flow) (Everett and Ruiz 1993; Crook and Robertson 1999), habitat for many animals (Lorion and Kennedy 2009b), and food for detritivores after they have been degraded by physical and biological processes (Murphy and Giller 2000). These structures make the establishment of a greater diversity of aquatic invertebrates possible (Schneider and Winemiller 2008), which, in turn, serve as food for fish (Angermeier and Karr 1984). In lotic systems, fruits, seeds and terrestrial invertebrates provided by riparian forest are important food items for ichthyofauna (Barili et al. 2011). The way in which such resources can serve as terrestrial subsidies for riverine consumers may vary among taxa and sites with different levels of canopy cover (Collins et al. 2016). Among terrestrial invertebrates, insects are widely consumed by several fish species (Esteves and Lobón-Cerviá 2001; Ferreira et al. 2012; Leite et al. 2015), especially if they occur at a higher abundance during a given time of year (Kawaguchi and Nakano 2001).

Because of this strong link between riparian and lotic ecosystems, the removal of forests is expected to disrupt allochthonous resource inputs and negatively affect the trophic structure of ichthyofauna (e.g., Wright and Flecker 2004; Leite et al. 2015). Over the past several years, the advancement of agriculture and cattle farming has been identified as the primary cause of deforestation in Brazilian rainforests (Morton et al. 2006; Santos et al. 2015). The Atlantic rainforest is among the eight hotspots with the highest biodiversity in the world, as it harbors an exceptional amount of endemic species that are suffering from habitat reduction (Myers et al. 2000). Originally, this biome covered 1 million $\mathrm{km}^{2}$ along the Brazilian coast, and currently, less than $8 \%$ remains due to the destruction caused by agriculture, urbanization and industrial development (Mamede et al. 2004). In the southeastern region, biodiversity is threatened mainly by the disorganized increase in human occupation that causes the illegal removal of the Atlantic forest and consequently habitat loss (Menezes et al. 2007). However, pollution, mining, invasion of exotic species, overfishing and illegal fishing for aquarism are also threats to the native ichthyofauna (Duboc and Menezes 2008; Barrella et al. 2014; Frehse et al. 2016). The Atlantic forest often exhibits a longitudinal gradient of degradation in which lowland areas are deforested, and the hilltops are preserved (e.g., Lobón-Cerviá et al. 2016), which is an important issue to address when evaluating fish diversity along the elevation profile in coastal regions (Terra et al. 2016). Changes in the taxonomic, functional and trophic structure of fishes are expected in the absence of forest cover (Teresa and Casatti 2012; Peressin and Cetra 2014) due to changes in water quality (Souza et al. 2013), habitat diversity and structure (Pusey and Arthington 2003), which consequently alter food availability (or trophic dynamics) (Ferreira et al. 2012) when the riparian forest is suppressed or reduced.

Despite the importance of riparian forests to aquatic organisms, very few studies have been conducted in tropical forested-protected areas to provide a reliable baseline (sensu Alagona et al. 2012) of species composition and biology. Pristine conditions (reference areas, sensu Hughes 1995) are currently very rare but extremely important when they are intended to incorporate biological information into environmental monitoring programs. Although there are studies that show the impact of deforestation on fish (e.g., Leite et al. 2015; Lobón-Cerviá et al. 2016), information about the trophic organization of fishes in pristine streams is still needed, which can also contribute to the evaluation of the protection efficiency of these areas. In this context, we described the trophic structure of coastal freshwater stream fishes in a pristine area of the Atlantic rainforest. Hence, we established that a forest-covered and protected area would be essential and the Juréia-Itatins, one of the largest forest remains in southeastern Brazil, was chosen. Because we studied the streams located in a preserved area of the Atlantic rainforest (Mamede et al. 2004), and because habitat quality is associated with the 
degree of integrity of a riparian forest (Casatti et al. 2012), we expect that the pristine condition of the forested streams would be reflected in the trophic structure of studied fish populations. Previous studies elsewhere indicate that riparian forest is one of the most important food sources for riverine fauna, such as fishes and macroinvertebrates (e.g., Gregory et al. 1991; Nakano et al. 1999). Considering the presence of riparian forests and the high diversity of insects in these environments (Colzani et al. 2013), we expect that insectivorous fishes will predominate and that the availability of resources provided by the forest will be constant due to the lack of seasonality in tropical forest (Esteves and Lobón-Cerviá 2001).

\section{Material and methods}

\section{Study area}

This study was conducted in the streams of the JuréiaItatins Ecological Station (JIES), one of the largest conservation areas with Atlantic forest fragments, situated on the Atlantic shore of the state of São Paulo, Brazil $\left(24^{\circ} 25^{\prime} \mathrm{S}, 47^{\circ} 15^{\prime} \mathrm{W}\right)$. It is located near the megalopolis of São Paulo, one of the most densely populated regions in Latin America with more than 20 million inhabitants, and much closer to Cubatão, one of the worst polluted industrial areas in the world (Por and Imperatriz-Fonseca 1984). The region is threatened by deforestation due to anthropogenic pressure, mostly by burgeoning urbanization. During the 70's and the early 80 's, the region suffered from strong pressure from landplot speculation and was considered by the Brazilian nuclear program for the installation of a nuclear power plant (Marques and Duleba 2004). Despite that, the JIES gained protection in 1987 to protect and ensure the integrity of ecosystems and comprises $\approx 80,000$ ha of practically untouched Atlantic rainforest (Por and Imperatriz-Fonseca 1984; Marques and Duleba 2004). Due to its harsh access, the area of the JIES is considered one of the best-preserved Atlantic forest remnants (Mamede et al. 2004).

The climate is subtropical humid without a pronounced dry season (Af type, according to Köeppen classification). The hotter and rainier season occurs from October to April, and the lesser rainy season occurs from May to September (Tarifa 2004). The mean rainfall and temperature are $2277 \mathrm{~mm}$ and $21.4^{\circ} \mathrm{C}$, respectively
(Marques and Duleba 2004). The hydrographic system of the JIES comprises different types of water, according to the topography, soil, and forest type in the drainage. Thus, the mountain streams that drain the Ombrophilous Atlantic Forest (Precambrian terrain) have clear waters and are poor in nutrients $(\mathrm{pH} \sim 5)$, while the lowland streams have black waters that are rich in humic substances ( $\mathrm{pH} \sim 4)$ due to the typical lowland "restinga" forest soils (alluvial, podzolic, and hydromorphic) (Por 1986, 2004; Por and Lopes 1994).

\section{Sampling}

Four samples were collected over a one-year period (April, July/August, November 2009, and February 2010) at seven streams, totaling 19 sample sites. Fishes were caught with electrofishing gear $(500 \mathrm{~V}, \mathrm{DC})$ in $50 \mathrm{~m}$-long reaches, according to the methods of Gonçalves and Braga (2012). Voucher specimens were deposited in the fish collection of the Department of Zoology and Botany (DZSJRP), São Paulo State University (UNESP), São José do Rio Preto, State of São Paulo, Brazil (DZSJRP 13234-13,258).

Terrestrial invertebrates and macroinvertebrates, which are considered potential food sources for fish, were sampled in the same $50 \mathrm{~m}$ reaches used for electrofishing. For terrestrial items, two pan traps (each with a surface area $\approx 800 \mathrm{~cm}^{2}$ ) were partially filled with soapy water, placed at each sample site (one at each wetted edge of the stream) and retrieved after $24 \mathrm{~h}$. Benthic macroinvertebrates were sampled with a Surber net (area $900 \mathrm{~cm}^{2}, 250 \mu \mathrm{m}$ mesh). The area delimited by the sampler was manually disturbed for $5 \mathrm{~min}$. To collect other aquatic items (e.g., crustaceans), four plastic minnow traps $(60 \times 20 \mathrm{~cm})$ were set near of the bottom of the stream edges for $24 \mathrm{~h}$, totaling 76 samplings. In addition, macroinvertebrates that were sampled with electrofishing were also counted. Invertebrates were fixed and later conserved in $70 \%$ ethanol. Food items and macroinvertebrates were identified according to Borror and Delong (1969), Fernández and Domínguez (2001), Costa et al. (2006), Mugnai et al. (2010) and Triplehorn and Johnson (2011).

In addition to terrestrial invertebrates, another important organic matter (energy) resource from allochthonous origin is plant litter, including leaves, fruits, seeds, flowers and wood (Wantzen et al. 2008). Considering that detritivorous fishes and several aquatic invertebrates that are preyed upon by fishes may feed on these 
sources after degradation, the allochthonous vegetal matter input sampled by the pan traps was also analyzed.

\section{Data analysis}

The diet of 20 fish species was determined by analyzing the stomach contents of 1691 individuals under a stereomicroscope. Individuals of species without differentiated stomachs (e.g., members of Loricariidae and Poeciliidae) had the contents of the first portion of the digestive tract analyzed via microscope. To determine the diets of the fishes, food items were grouped into broad categories: Bryozoa, Nematoda, Mollusca, Annelida, Arachnida, Crustacea, Diplopoda, Chilopoda, Collembola, Insecta, Amphibia, Actinopterygii, vegetal matter, periphyton, and detritus (particulate organic matter). A wide range of organic matter, i.e., dead plant and animal material, composed the detritus (Wantzen et al. 2008). The lowest (order) level was used for insects to calculate the $I R I$ and $E$ indexes (see below). The presence of sand (inorganic matter) was also registered. We analyzed the diet of all species caught with the exception of Hoplias malabaricus (Erythrinidae) and Synbranchus marmoratus (Synbranchidae), which did not have food content in the stomachs.

The origins of the food resources were evaluated to verify the importance of the riparian forest to the fish diets. Therefore, food items were classified as allochthonous (terrestrial items), autochthonous (aquatic items) or of indeterminate origin. The frequency of occurrence of these resources in the diet of the species and in the environment (i.e., food resource availability considering only streams where the species occurred) was evaluated graphically.

The diets were analyzed based on the occurrence $(O$, $\%)$, weight $(W, \%)$, and number $(N, \%)$ of each food item $(i)$. The alimentary index $(A I, \%)$, proposed by Kawakami and Vazzoler (1980), was calculated with modification (for better accuracy, the volume was replaced by the weight of the food items), as: $A I_{i}={ }^{O_{i}{ }^{*} W_{i}} / \Sigma f=1^{n}\left(O_{i} * W_{i}\right)$. Since insects are preyed on by several stream fishes, the index of relative importance (IRI) (Pinkas et al. 1971) and the index of electivity $(E)$ (Ivlev 1961) were used to evaluate the importance and selectivity in the diets of insectivorous fishes, as follows. The IRI (\%) was calculated to determine the predominant taxon (order level) in the diet of the insectivorous fishes, replacing the volume by the weight of food items (also for better accuracy), as: $I R I=$ $(N+W) * O$. The feeding selectivity of the fish was evaluated using $E$, establishing the proportion of each insect order consumed by the fish species to each insect order available in the environment, as: $E_{i}={ }^{\left(r_{i}-P_{i}\right)} /_{\left(r_{i}+P_{i}\right)}$, where $r_{i}$ is the frequency of occurrence (\%) of each insect order $i$ in the stomach contents of the fish, and $P_{i}$ is the frequency of occurrence (\%) of each insect order $i$ available in the environment. $E$ ranges from -1 to +1 , and the selectivity is considered positive when $E>0$, negative when $E<0$ and absent when $E=0$ (Ivlev 1961).

To verify the seasonal dependency of the diet, the values of $A I$ obtained from each sample during the study (four samples) were tested by a Kruskal-Wallis test. Similarly, the biomass of the food resources, i.e., availability of prey items from each sample (four samples), was evaluated to verify the seasonal dependency using a Kruskal-Wallis test. The species occurrence was considered to determine the availability of the food resource to each species. These analyses were performed using $\mathrm{R}$, version 3.0.3 (R Development Core Team 2014).

A simple agglomerative hierarchical clustering analysis was applied to determine the feeding habits, considering the $A I$ values of each food item consumed by the fish species. The Bray-Curtis index and the single linkage method were used, and the data were standardized to simplify the relationships (Legendre and Legendre 1998). A SIMPROF (similarity profile) permutation test was used to determine the significant differences among the clusters (999 permutations). The null hypothesis considers that samples are not a priori divided into groups. The cluster and SIMPROF analyses were performed using PRIMER 6 (Clarke and Gorley 2006).

The significance level $\alpha=5 \%$ was established for the statistical analyses.

\section{Results}

Of the 24 food items consumed by the fishes, ten were allochthonous, ten were autochthonous and four were of indeterminate origin (Table 1). Terrestrial and aquatic insects and detritus were the most commonly consumed food items and prevailed in the diet of five, ten, and six species, respectively (Table 1). The results of the Kruskal-Wallis tests indicated that the diet and food 
Table 1 Specimens' abundance and number of stomachs analyzed for each fish species in streams of Juréia-Itatins Ecological Station, between April 2009 and February 2010

\begin{tabular}{|c|c|c|c|c|c|c|c|}
\hline & Digu & Mmic & Phar & Hmul & Clan & Pobt & Alep \\
\hline Specimens & 1032 & 853 & 660 & 353 & 171 & 112 & 94 \\
\hline Stomachs & 492 & 436 & 40 & 272 & 115 & 56 & 60 \\
\hline \multicolumn{8}{|l|}{ Allochthonous items } \\
\hline Nematoda & & 0.00003 & & 0.004 & & & \\
\hline Annelida & 0.05 & & & 0.004 & & & 3.27 \\
\hline Arachnida & 0.04 & 0.28 & & 0.52 & 0.001 & & 0.15 \\
\hline Crustacea & 0.0002 & 0.001 & & 0.0005 & & & 0.52 \\
\hline Diplopoda & 0.08 & & & 0.02 & & & \\
\hline Chilopoda & & & & 0.001 & & & \\
\hline Collembola & 0.0002 & 0.05 & & 0.0001 & & & 0.01 \\
\hline Insecta & 17.17 & 78.76 & & 90.11 & 0.05 & & 2.96 \\
\hline Vegetal matter & 4.95 & 0.03 & & 0.59 & & & \\
\hline Detritus/Organic matter & 25.97 & & 99.999 & 0.65 & & 98.53 & \\
\hline \multicolumn{8}{|l|}{ Autochthonous items } \\
\hline Bryozoa & 0.003 & & & & & & \\
\hline Nematoda & 0.0001 & 0.0002 & & 0.002 & & & 0.01 \\
\hline Mollusca & 0.0001 & 0.001 & & & 0.003 & & 0.02 \\
\hline Arachnida & 0.000003 & 0.00001 & & 0.000003 & 0.0004 & & \\
\hline Crustacea & 0.22 & 0.10 & & 1.75 & 0.1 & 0.004 & 5.24 \\
\hline Insecta & 22.35 & 12.49 & 0.001 & 4.15 & 99.87 & 0.01 & 86.49 \\
\hline Amphibia & & & & 0.01 & & & \\
\hline Actinopterygii & & & & 0.14 & & & \\
\hline Vegetal matter & 25.40 & & & 0.02 & 0.01 & & \\
\hline Periphyton & 1.78 & & & & & 1.46 & \\
\hline \multicolumn{8}{|l|}{ Indeterminate origin } \\
\hline Nematoda & & & & & & & 0.02 \\
\hline Arachnida & & 0.00004 & & & & & \\
\hline Insecta & 1.86 & 8.29 & & 2.01 & 0.01 & & 1.29 \\
\hline Vegetal matter & 0.12 & & & 0.01 & & & 0.003 \\
\hline Indeterminate & 0.01 & 0.00001 & & 0.000001 & & & \\
\hline Sand/Inorganic matter & present & present & present & present & & present & present \\
\hline Trophic guilds & $\mathrm{O}$ & IS & $\mathrm{D}$ & IS & IS & $\mathrm{D}$ & IS \\
\hline KW test (diet) & $\begin{array}{l}H=1.75 \\
\mathrm{df}=3 \\
p=0.63\end{array}$ & $\begin{array}{l}\mathrm{H}=0.27 \\
\mathrm{df}=3 \\
p=0.97\end{array}$ & - & $\begin{array}{l}\mathrm{H}=2.98 \\
\mathrm{df}=3 \\
p=0.39\end{array}$ & $\begin{array}{l}\mathrm{H}=1.08 \\
\mathrm{df}=3 \\
p=0.78\end{array}$ & $\begin{array}{l}\mathrm{H}=4.55 \\
\mathrm{df}=3 \\
p=0.21\end{array}$ & $\begin{array}{l}\mathrm{H}=3.35 \\
\mathrm{df}=3 \\
p=0.34\end{array}$ \\
\hline \multirow[t]{2}{*}{ KW test (food resources) } & $\begin{array}{l}\mathrm{H}=2.28 \\
\mathrm{df}=3 \\
p=0.52\end{array}$ & $\begin{array}{l}\mathrm{H}=1.84 \\
\mathrm{df}=3 \\
p=0.61\end{array}$ & $\begin{array}{l}\mathrm{H}=2.56 \\
\mathrm{df}=3 \\
p=0.46\end{array}$ & $\begin{array}{l}H=1.62 \\
\mathrm{df}=3 \\
p=0.65\end{array}$ & $\begin{array}{l}\mathrm{H}=1.85 \\
\mathrm{df}=3 \\
p=0.60\end{array}$ & $\begin{array}{l}H=1.82 \\
d f=3 \\
p=0.61\end{array}$ & $\begin{array}{l}H=2.27 \\
\mathrm{df}=3 \\
\mathrm{p}=0.52\end{array}$ \\
\hline & Rque & Ataj & Sgun & Gpan & Hgri & Asan & Csch \\
\hline Specimens & 66 & 63 & 58 & 48 & 41 & 39 & 35 \\
\hline Stomachs & 27 & 20 & 20 & 34 & 18 & 24 & 29 \\
\hline \multicolumn{8}{|l|}{ Allochthonous items } \\
\hline \multicolumn{8}{|l|}{ Nematoda } \\
\hline Annelida & 44.82 & 0.25 & & 10.96 & & & \\
\hline Arachnida & 0.03 & & & & & 0.92 & \\
\hline
\end{tabular}


Table 1 (continued)

\begin{tabular}{|c|c|c|c|c|c|c|c|}
\hline \multicolumn{4}{|l|}{ Crustacea } & \multicolumn{4}{|l|}{0.001} \\
\hline Diplopoda & 11.27 & & & & & & \\
\hline \multicolumn{8}{|l|}{ Chilopoda } \\
\hline Collembola & & & & & 0.05 & & \\
\hline Insecta & 12.69 & & & 9.65 & 31.93 & 55.10 & 4.01 \\
\hline Vegetal matter & 0.06 & & & 0.56 & & & \\
\hline Detritus/Organic matter & & 8.88 & 93.55 & & & & 0.001 \\
\hline \multicolumn{8}{|l|}{ Autochthonous items } \\
\hline \multicolumn{8}{|l|}{ Bryozoa } \\
\hline \multicolumn{8}{|l|}{ Nematoda } \\
\hline Mollusca & 0.0001 & 0.18 & & & & & \\
\hline Arachnida & & & & & & 0.05 & \\
\hline Crustacea & 12.35 & 0.63 & & 9.18 & & 1.18 & 1.43 \\
\hline Insecta & 5.85 & 89.93 & & 62.39 & 23.98 & 42.29 & 94.44 \\
\hline \multicolumn{8}{|l|}{ Amphibia } \\
\hline Actinopterygii & 10.33 & & & 0.01 & & & \\
\hline Vegetal matter & 0.0004 & 0.11 & & 0.19 & & & \\
\hline Periphyton & & 0.02 & 6.45 & & & & 0.001 \\
\hline \multicolumn{8}{|l|}{ Indeterminate origin } \\
\hline \multicolumn{8}{|l|}{ Nematoda } \\
\hline \multicolumn{8}{|l|}{ Arachnida } \\
\hline Insecta & 2.59 & 0.00 & & 6.99 & 43.86 & & 0.11 \\
\hline Vegetal matter & 0.0001 & & & & 0.17 & & \\
\hline Indeterminate & & & & 0.07 & & 0.46 & \\
\hline Sand/Inorganic matter & present & & present & present & & & present \\
\hline Trophic guilds & $\mathrm{CA}$ & IS & $\mathrm{D}$ & IS & IS & IS & IS \\
\hline \multirow[t]{3}{*}{ KW test (diet) } & $\mathrm{H}=3.58$ & $\mathrm{H}=2.79$ & $\mathrm{H}=0$ & $\mathrm{H}=5.53$ & $\mathrm{H}=3.27$ & $\mathrm{H}=1.20$ & $\mathrm{H}=1.30$ \\
\hline & $\mathrm{df}=3$ & $\mathrm{df}=3$ & $\mathrm{df}=2$ & $\mathrm{df}=3$ & $\mathrm{df}=2$ & $\mathrm{df}=3$ & $\mathrm{df}=3$ \\
\hline & $p=0.31$ & $p=0.43$ & $p=1$ & $p=0.14$ & $p=0.19$ & $p=0.75$ & $p=0.73$ \\
\hline \multirow[t]{4}{*}{ KW test (food resources) } & $\mathrm{H}=3.23$ & $\mathrm{H}=3.32$ & $\mathrm{H}=2.36$ & $\mathrm{H}=2.51$ & $\mathrm{H}=0.48$ & $\mathrm{H}=0.33$ & $\mathrm{H}=3.18$ \\
\hline & $\mathrm{df}=3$ & $\mathrm{df}=3$ & $\mathrm{df}=3$ & $\mathrm{df}=3$ & $\mathrm{df}=3$ & $\mathrm{df}=3$ & $\mathrm{df}=3$ \\
\hline & $p=0.36$ & $p=0.35$ & $p=0.50$ & $p=0.47$ & $p=0.92$ & $p=0.95$ & $p=0.37$ \\
\hline & Hret & Khey & Gbra & Epis & Smac & Dmac & \\
\hline Specimens & 27 & 24 & 21 & 18 & 11 & 9 & \\
\hline Stomachs & 18 & 4 & 6 & 10 & 8 & 2 & \\
\hline \multicolumn{8}{|l|}{ Allochthonous items } \\
\hline \multicolumn{8}{|l|}{ Nematoda } \\
\hline \multicolumn{8}{|l|}{ Annelida } \\
\hline \multicolumn{8}{|l|}{ Arachnida } \\
\hline \multicolumn{8}{|l|}{ Crustacea } \\
\hline Diplopoda & & & & & & & \\
\hline Chilopoda & & & & & & & \\
\hline Collembola & 0.01 & & & & & & \\
\hline Insecta & 9.22 & & 1.46 & & & & \\
\hline Vegetal matter & 1.02 & & 0.18 & & & & \\
\hline Detritus/Organic matter & & 94.61 & 0.40 & & & 96.77 & \\
\hline Autochthonous items & & & & & & & \\
\hline Bryozoa & & & & & & & \\
\hline Nematoda & 0.01 & & 0.01 & & & & \\
\hline Mollusca & & & 0.04 & & & & \\
\hline Arachnida & & & & & & & \\
\hline Crustacea & & & 22.32 & 93.10 & & & \\
\hline Insecta & 4.00 & & 75.48 & 5.93 & 99.82 & 3.23 & \\
\hline Amphibia & & & & & & & \\
\hline Actinopterygii & & & & & & & \\
\hline Vegetal matter & & & & & & & \\
\hline Periphyton & & 5.39 & & & 0.18 & & \\
\hline
\end{tabular}


Table 1 (continued)

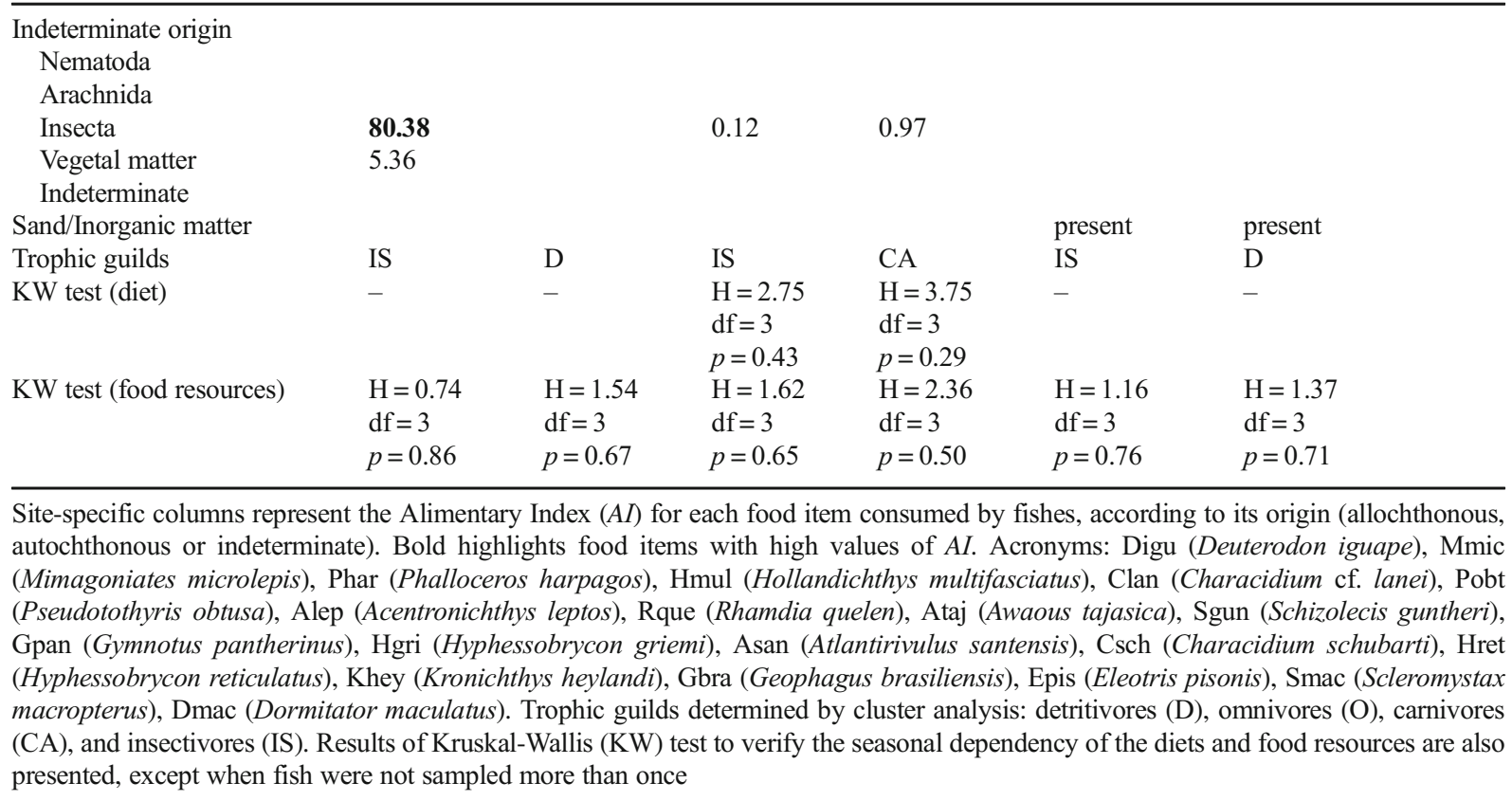

resource availability were not seasonally dependent for any of the species (Table 1).

The cluster analysis categorized the fish feeding habits according to the similarity of the food categories preyed upon (Fig. 1). The dendrogram showed five significant trophic guilds (SIMPROF, $p<0.05$ ): terrestrial insectivores (predominance of terrestrial insects), aquatic insectivores (predominance of immature aquatic insects), detritivores (predominance of detritus), carnivores (if the diet included fish or shrimp in addition to other invertebrates) and omnivorous (plant/animal food resources and detritus in similar proportions) species (Fig. 1, Table 1). Insectivores predominated in species richness $(60 \%)$, abundance (47\%) and biomass (39\%) (Fig. 2).

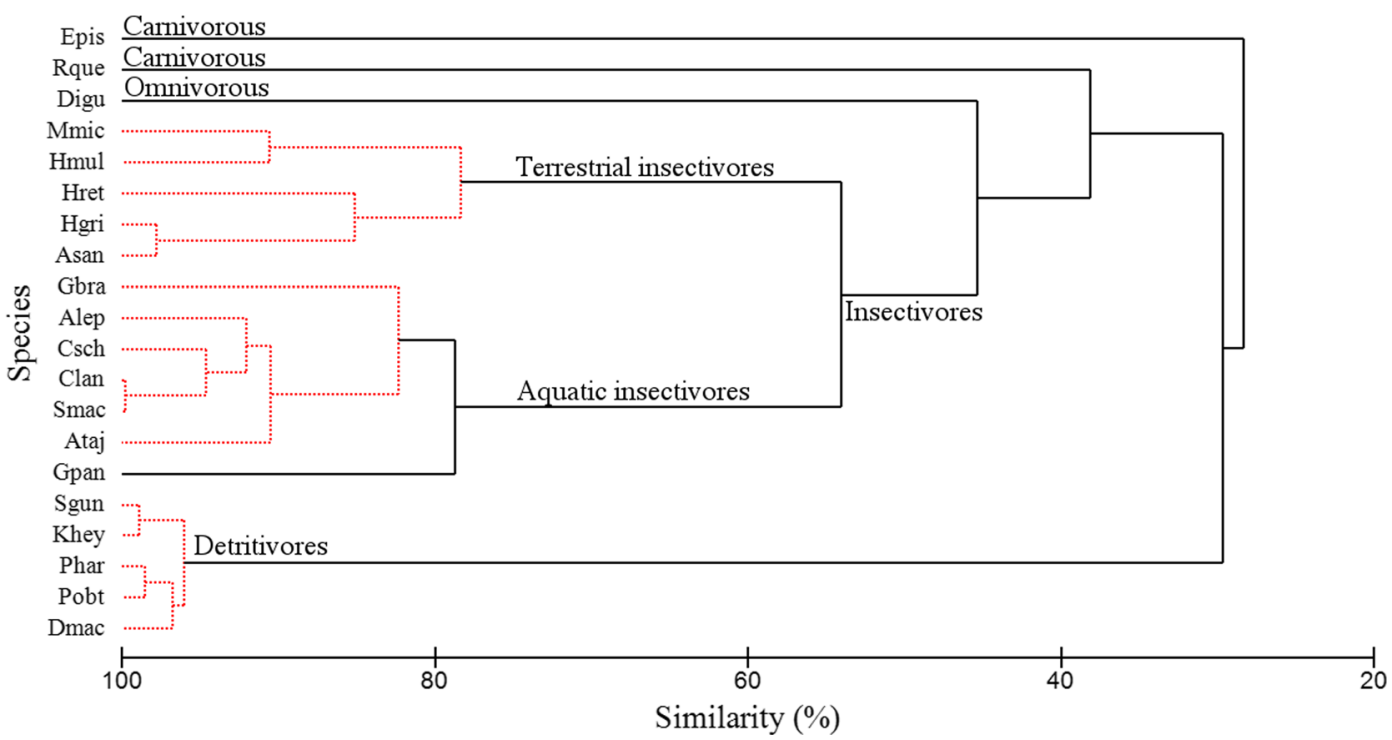

Fig. 1 Dendrogram resulted from the cluster analysis, indicating the fish trophic guilds. Dotted lines connect fish species that do not differ in terms of feeding habits (SIMPROF, $p>0.05$ ). See Table 1 for species acronyms 
Fig. 2 Species richness, abundance and biomass of fish trophic guilds $\square$ Richness $\square$ Abundance $\square$ Biomass

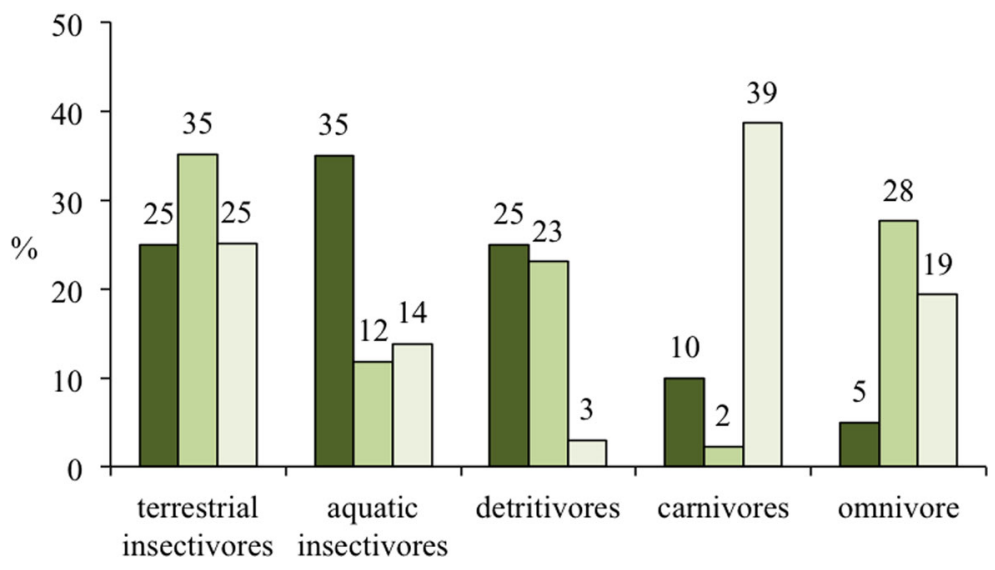

Food items of allochthonous origin were representative in the diets of Mimagoniates microlepis (Characidae), Phalloceros harpagos (Poeciliidae), Hollandichthys multifasciatus (Characidae), Pseudotothyris obtusa (Loricariidae), Schizolecis guntheri (Loricariidae) and Kronichthys heylandi (Loricariidae), whereas items of autochthonous origin were important for Characidium lanei (Crenuchidae), Acentronichthys leptos (Heptapteridae), Awaous tajasica (Gobiidae), Gymnotus pantherinus (Gymnotidae), C. schubarti (Crenuchidae), Geophagus brasiliensis (Cichlidae), Eleotris pisonis (Eleotridae) and Scleromystax macropterus (Callichthyidae) (Fig. 3a). Food items of both origins were consumed in similar proportions by Deuterodon iguape (Characidae), Rhamdia quelen (Heptapteridae), Schizolecis guntheri (Loricariidae), Hyphessobrycon griemi (Characidae) and Atlantirivulus santensis (Rivulidae) (Fig. 3a).
Fig. 3 Food resources consumed by fish species (a), and available in the environment for each species (b), according to its origin. See Table 1 for species acronyms a $\square$ Allochthonous $\square$ Autochthonous $\square$ Indeterminate

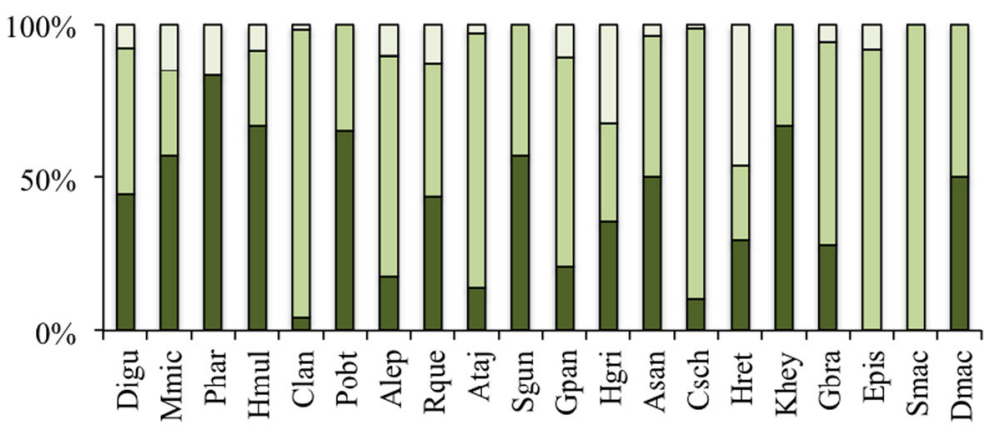

b $\square$ Allochthonous $\square$ Autochthonous $\square$ Indeterminate

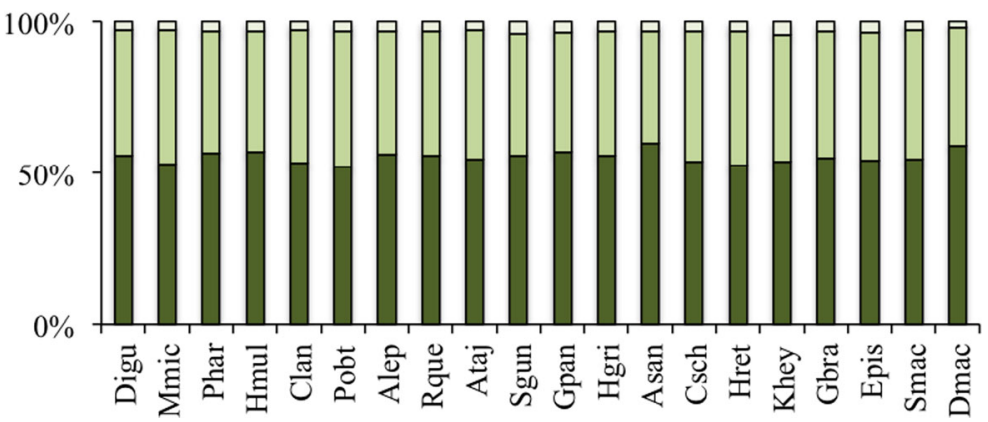


Considering the availability of food resources, allochthonous and autochthonous items were found in similar proportions in the environment for all species (Fig. 3b).

Diptera, Hymenoptera and Ephemeroptera were the most abundant insect orders in the environments (Table 2). For all fish species (except $S$. macropterus), the most frequently consumed food resource was also considered the most important by the IRI (Table 2). Overall, many insectivorous species ingested items considered important by the IRI that were positively selected $(E>0)$ (Table 2). Most insectivorous fish presented specialized diets: terrestrial insectivores (M. microlepis and $H$. multifasciatus) preferentially consumed $(E \geq 0.5)$ allochthonous insects and avoided $(E<0)$ the intake of autochthonous insects, while aquatic insectivores $(C$. lanei, A. leptos, A. tajasica, C. schubarti, $S$. macropterus) preferentially consumed $(E \geq 0.5)$ autochthonous insects and avoided $(E<0)$ the ingestion of allochthonous insects (Table 3 ). No evident pattern was detected for the insectivores that fed on insects of indeterminate origin (H. reticulatus) or of allochthonous and autochthonous origin in similar proportions $(H$. griemi, A. santensis) (Table 3).

\section{Discussion}

The presence of insectivorous fishes in the JIES was expressive and reflected what was expected since many insectivores and few omnivores were expected in this high-integrity forest. We studied microbasins with very little anthropogenic interference and were, therefore, covered by high-quality forests, including a riparian buffer. Thus, the high quality of the riparian buffer is transferred to the aquatic environment. In these conditions, the fish fauna is predominantly composed of species with specialized habits and insectivorous diets, as opposed to degraded environments, where generalist habits predominate and omnivory, as well as trophic redundancy, is more frequently observed (Casatti et al. 2012; LobónCerviá et al. 2016; Ceneviva-Bastos et al. 2017).

The importance of riparian forests for maintaining the quality of the aquatic environment is well documented in the literature (e.g., Sweeney and Newbold 2014). Many stream fish species require specific conditions and resources and depend on the importation of material from the surrounding forest (Schlosser 1991). Microhabitat preference is closely related to the morphological traits of fishes (Manna et al. 2017). In the JIES streams, different micro and mesohabitats that are formed by combinations of substrate types, depths and water velocities (Gonçalves and Braga 2012) can be exploited by fish from different groups. Indeed, the 12 insectivores were distributed in two functional feeding groups. They were represented by the terrestrial insectivores that explore the entire water column (e.g., Hollandichthys multifasciatus and Mimagoniates microlepis) and are frequently found in deep pools with lentic waters and sandy substrates (Sabino and Castro 1990) and by species that predominantly exploit the bottom, such as aquatic insectivores (e.g., Characidium lanei and $C$. schubarti) who prefer environments with opposite characteristics that are common in lotic reaches (Sabino and Silva 2004; Terra et al.2016). The in-stream variability provided by higher habitat complexity can harbor more diverse aquatic food webs (Ceneviva-Bastos et al. 2017). Therefore, functional complementarity is evident in forested streams (Bordignon et al. 2015), unlike deforested streams where the communities are redundant (Casatti et al. 2015).

In addition to the diversity of habitats, food availability is an important factor for ichthyofauna organization (Uieda and Pinto 2011; Leite et al. 2015). In lotic ecosystems, many processes are determined by their interface with riparian ecosystems, and this link is more accentuated in streams because they are naturally narrow (Gregory et al. 1991). The contribution of organic matter is higher in closed canopy sites (see Wantzen et al. 2008 for examples). We are aware that the implications of this allochthonous contribution to the energy flow through aquatic food chains in tropical streams are still unclear (Wantzen et al. 2008). Despite this, we agree that this potential input of terrestrial energy derived mainly from trunks, branches and leaves of the riparian forest (while in degraded environments the proliferation of macrophytes occurs and the source of organic matter is autochthonous) may favor the presence of detritivorous organisms, such as fish and macroinvertebrates. Forest litter may not be consumed directly by detritivores, but after its degradation, this source of organic matter becomes available as particulate organic matter (POM) or fine particulate organic matter (FPOM). In the JIES, P. obtusa and $S$. guntheri are relatively abundant species (Gonçalves and Braga 2012), and the occurrence of these detritivorous fish was probably favored by the food supply. 


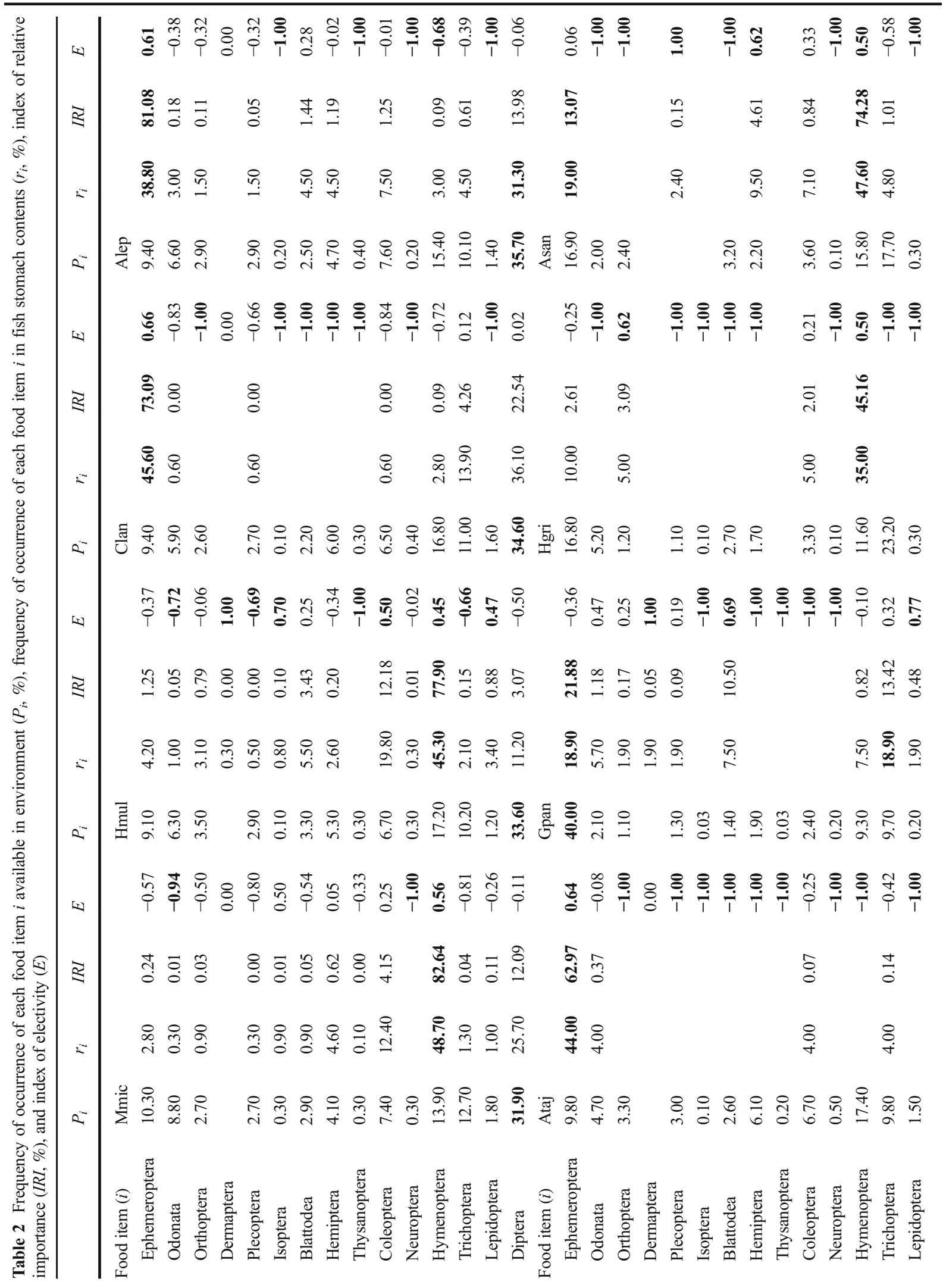




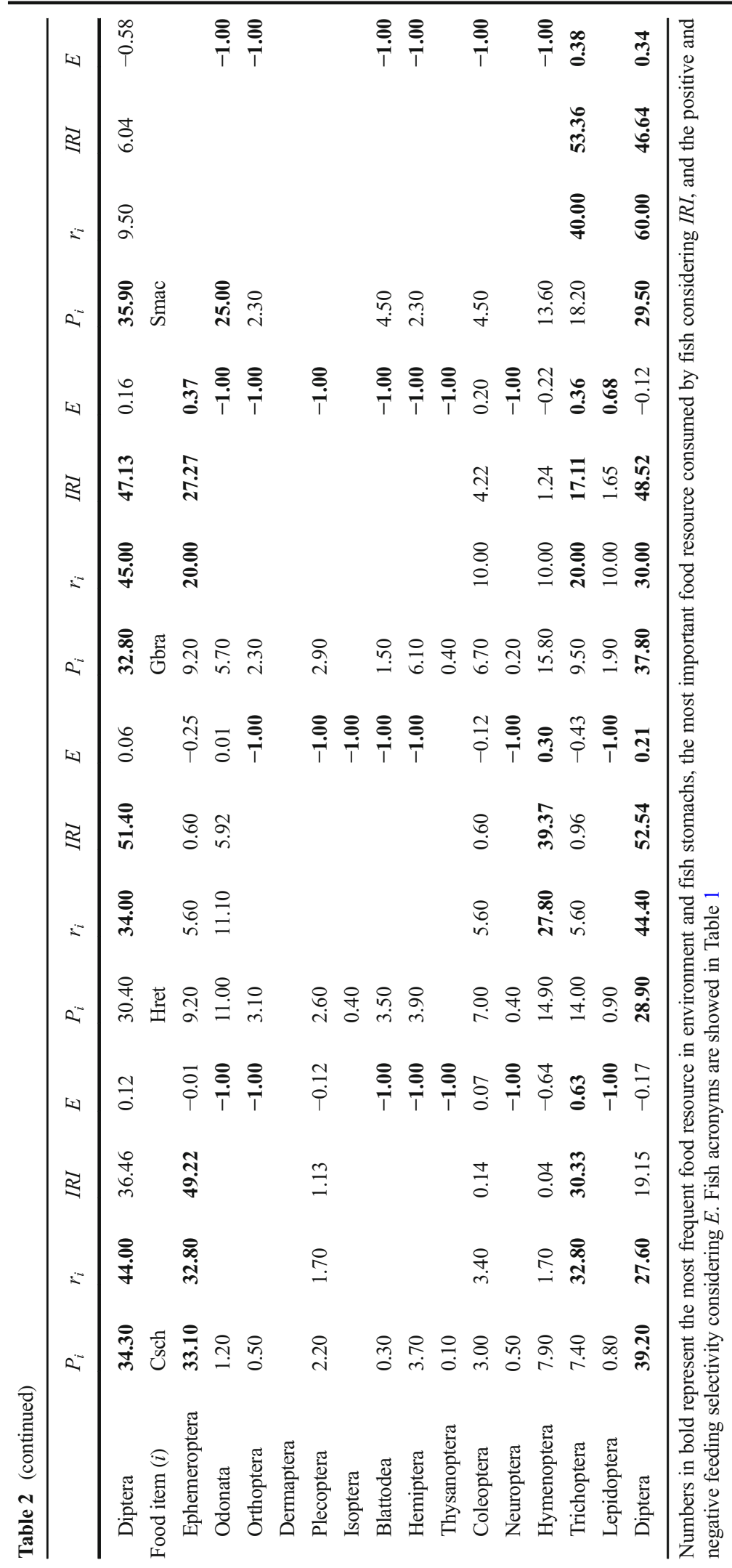




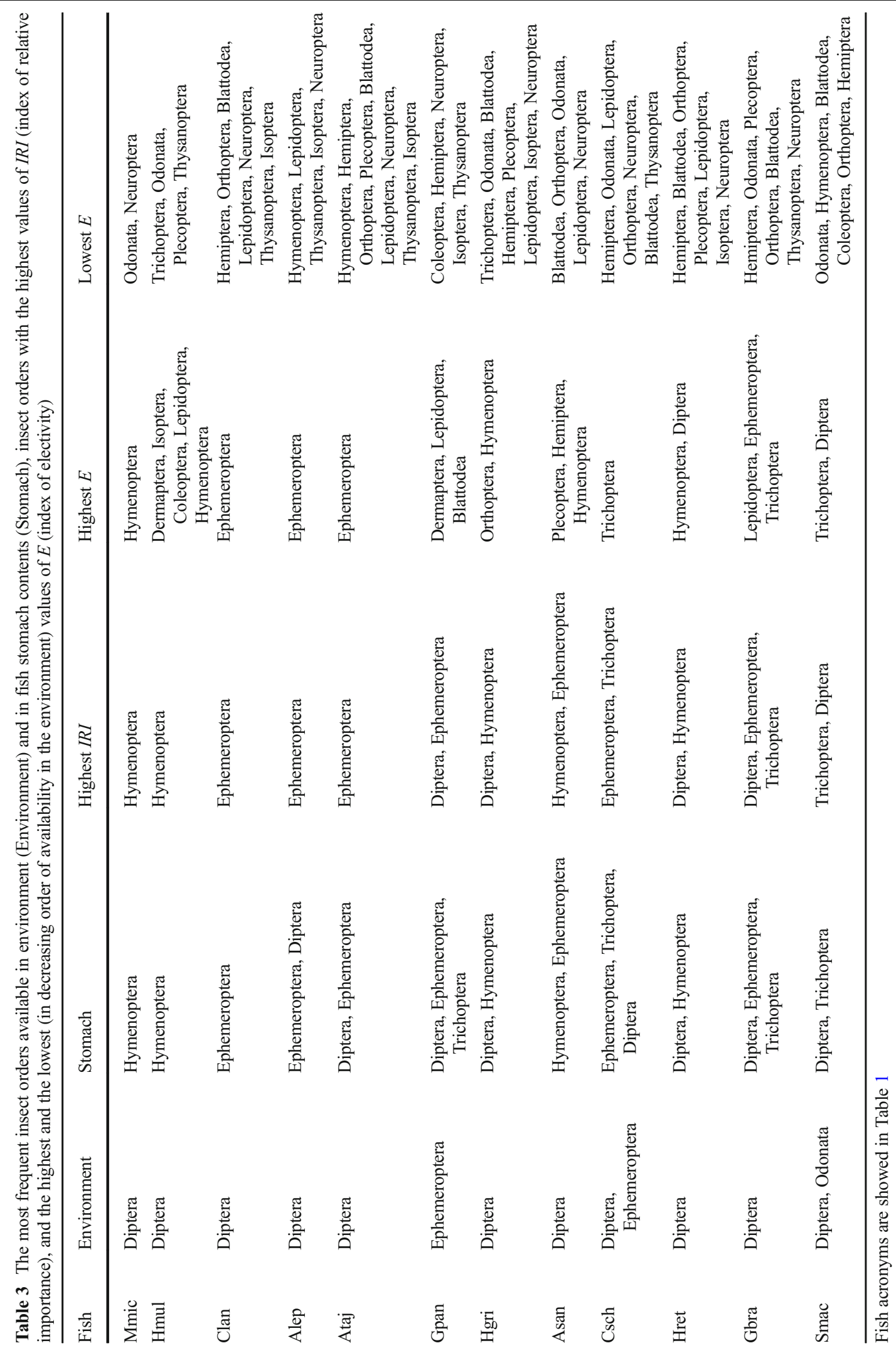


On the other hand, aquatic insectivorous fishes indirectly benefit from the contribution of organic matter from the forest, since many aquatic insects, mainly immature forms, feed on debris and plant remains (Boulton and Lake 1992), especially POM and FPOM that are carried by the runoff and accumulate at the bottom of the stream (Galdean et al. 2001). Thus, riparian forests sustain the aquatic food webs through the detritus chain, as they provide organic matter for the consumption of detritivorous invertebrates (and fishes), which will serve as food for insectivorous fishes (Rosemond et al. 2001). Although the origins of the detritus were not determined by laboratory analysis, the pristine condition of the forest cover of the JIES (Mamede et al. 2004) and the non-significant presence of macrophytes in the studied streams (personal observation) allow us to assume that the forest acts as the main donor of these resources. In addition, terrestrial insects were important in the diet of most Characidae species, such as H. multifasciatus, M. microlepis, D. iguape, and H. griemi (except H. reticulatus), which is consistent with previous findings in other coastal Brazilian streams (e.g., Sabino and Castro 1990; Esteves and Lobón-Cerviá 2001; Deus and Petrere Jr 2003; Wolff et al. 2013) and is also a good indicator of the donation of food resources by the riparian forest.

Allochthonous and autochthonous items were available in very similar quantities. Despite the similarity, these items were differently consumed by fish, which in some extent reveals the preferences for certain food resources. Indeed, most insectivorous fish presented food selectivity. For example, allochthonous items were important for characins (M. microlepis and H. multifasciatus) that fed mostly on terrestrial insects that fell on the water surface. These fish are extremely active in the water column, easily attracted by materials from the riparian forest that fall on the water surface (Sabino and Sazima 1999; Gomiero et al. 2008), and are frequently classified as surface pickers (Sazima 1986), which explains their high consumption of terrestrial insects. Autochthonous resources, by contrast, were important mainly for C. lanei, A. leptos, A. tajasica, C. schubarti and $S$. macropterus, which fed mostly on benthic insects. These fish occupy a bottom position in the stream channel (Sabino and Castro 1990; Sabino and Silva 2004; Gonçalves and Cestari 2013), which facilitates the foraging and consumption of insects that inhabit the substrate. They also have several foraging tactics to explore the stream bottom (e.g., grubbers excavating while moving, sitand-wait and crepuscular predators of bottom animals, sensu Sazima 1986).

In this study, we did not observe temporal variations in fish diet, nor in the availability of food resources. In the coastal Atlantic rainforest, the absence of seasonality is common due to high humidity and low variation in the rainfall regime (Talora and Morellato 2000). Although streams are highly dynamic environments where torrential rains can increase water flow over short periods, rainfall in the Atlantic rainforest is high and well distributed throughout the year (Esteves and Lobón-Cerviá 2001). These characteristics were reported for the JIES (Marques and Duleba 2004; Tarifa 2004) and contributed to the seasonally independent distribution of ichthyofauna (Gonçalves and Braga 2012). These findings agree with other records for tropical coastal streams (Esteves and Lobón-Cerviá 2001; Lorion and Kennedy 2009b) and for macroinvertebrates (Lorion and Kennedy 2009a), which is in agreement with our prediction that resource availability would be constant throughout of the year. Therefore, the absence of seasonal variation in the fish diet is possibly related to the consistent food supply over time.

We were able to provide evidence on the role of the riparian forest as a food provider for stream fishes. For example, several terrestrial insects besides ants, a very common terrestrial food resource for insectivorous fishes in deforested tropical streams (Ceneviva-Bastos and Casatti 2007; Lobón-Cerviá et al. 2016), and detritus derived mainly from degraded woody debris and fallen leaves (also consumed by many aquatic insects, which subsequently serve as food for fish) were important food sources, highlighting the importance of adjacent forest-covered areas as donor systems, especially to oligotrophic headwater streams such as those in the JIES. Many human activities alter land use and degrade the environment, which can reduce or even disrupt the connection between fish and the forest. Considering the increasing human population in the coastal region, our results emphasize the importance of protecting the Atlantic forest areas with conservation units such as the JIES to maintain the function, quality and integrity of the aquatic ecosystems and consequently the associated biota such as fish. Finally, our study provides a reliable baseline scenario to subsidize ecological restoration projects in similar environments within the Atlantic biome. 
Acknowledgments We are indebted to César Cestari, Ílson Prado and Rubens Rogério de Prado for their dedication in the field, Francisco Langeani and Naércio Menezes who identified the fish species, Edilberto Gianotti who helped with the identification of invertebrates and José Sabino for suggestions on an earlier version of this manuscript. We also thank FAPESP (2008/550295) and CAPES, who financially supported this project. CSG received a grant from FAPESP (2012/19723-0), FMSB and LC from CNPq. Fish and invertebrate sampling protocols were approved by IBAMA/ICMBio (\#15744-1, \#15744-2) and COTEC (\#260108-000.197/0 2008). We followed all applicable guidelines for the care and use of animals.

\section{References}

Alagona PS, Sandlos J, Wiersma YF (2012) Past imperfect: using historical ecology and baseline data for conservation and restoration projects in North America. Environ Philos 9:4970

Anderson NH, Sedell JR (1979) Detritus processing by macroinvertebrates in stream ecosystems. Annu Rev Entomol 24: 351-377. https://doi.org/10.1146/annurev. en.24.010179.002031

Angermeier PL, Karr JR (1984) Relationships between woody debris and fish habitat in a small warmwater stream. T Am Fish Soc 113:716-726. https://doi.org/10.1577/1548-8659

Barili E, Agostinho AA, Gomes LC, Latini JD (2011) The coexistence of fish species in streams: relationships between assemblage attributes and trophic and environmental variables. Environ Biol Fish 92:41-52. https://doi.org/10.1007 /s10641-011-9814-2

Barrella W, Martins AG, Petrere M Jr, Ramires M (2014) Fishes of the southeastern Brazil Atlantic Forest. Environ Biol Fish 97: 1367-1376. https://doi.org/10.1007/s10641-014-0226-y

Bordignon CR, Casatti L, Pérez-Mayorga MA, Teresa FB, Brejão GL (2015) Fish complementarity is associated to forests in Amazonian streams. Neotrop Ichthyol 13:579-590. https://doi.org/10.1590/1982-0224-20140157

Borror DJ, Delong DM (1969) Introdução ao estudo de insetos. Edgard Blücher Ltda, São Paulo

Boulton AJ, Lake PS (1992) Benthic organic matter and detritivorous macroinvertebrates in two intermittent streams in south-eastern Australia. Hydrobiologia 241:107-118. https://doi.org/10.1007/BF00008263

Casatti L, Teresa FB, Gonçalves-Souza T, Bessa E, Manzotti AR, Gonçalves CS, Zeni JO (2012) From forests to cattail: how does the riparian zone influence stream fish? Neotrop Ichthyol 10:205-214. https://doi.org/10.1590/S167962252012000100020

Casatti L, Teresa FB, Zeni JO, Ribeiro MD, Brejão GL, CenevivaBastos (2015) More of the same: high functional redundancy in stream fish assemblages from tropical agroecosystems. Environ Manag 55:1300-1314. https://doi.org/10.1007 /s00267-015-0461-9

Ceneviva-Bastos M, Casatti L (2007) Oportunismo alimentar de Knodus moenkhausii (Teleostei, Characidae): uma espécie abundante em riachos do noroeste do Estado de São Paulo, Brasil. Iheringia Sér Zool 97:7-15. https://doi.org/10.1590 /S0073-47212007000100002

Ceneviva-Bastos M, Montaña C, Schalk C, Camargo PB, Casatti L (2017) Responses of aquatic food webs to the addition of structural complexity and basal resource diversity in degraded Neotropical streams. Austral Ecol. https://doi.org/10.1111 /aec. 12518

Clarke KR, Gorley RN (2006) PRIMER v6: user manual/tutorial. PRIMER-E, Plymouth

Collins SM, Kohler TJ, Thomas SA, Fetzer WW, Flecker AS (2016) The importance of terrestrial subsidies in stream food webs varies along a stream size gradient. Oikos 125:674685. https://doi.org/10.1111/oik.02713

Colzani E, Siqueira T, Suriano MT, Roque FO (2013) Responses of aquatic insect functional diversity to landscape changes in Atlantic forest. Biotropica 45:343-350. https://doi. org/10.1111/btp.12022

Costa C, Ide S, Simonka CE (2006) Insetos imaturos: metamorfose e identificação. Holos, Ribeirão Preto

Crook DA, Robertson AI (1999) Relationships between riverine fish and woody debris: implications for lowland rivers. Mar Freshw Res 50:941-953. https://doi.org/10.1071/MF99072

Cummins KW (1974) Structure and function of stream ecosystems. Bioscience 24:631-641. https://doi.org/10.2307 $/ 1296676$

Deus CP, Petrere M Jr (2003) Seasonal diet shifts of seven fish species in an Atlantic rainforest stream in southeastern Brazil. Braz J Biol 63:579-588. https://doi.org/10.1590/S151969842003000400005

Duboc LF, Menezes NA (2008) Peixes. In: Machado ABM, Drummond GM, Paglia AP (eds) Livro Vermelho da Fauna Brasileira Ameaçada de Extinção. Belo Horizonte, Biodiversitas

Esteves KE, Lobón-Cerviá J (2001) Composition and trophic structure of a fish community of a clear water Atlantic rainforest stream in southeastern Brazil. Environ Biol Fish 62:429-440. https://doi.org/10.1023/A:1012249313341

Everett RA, Ruiz GM (1993) Coarse woody debris as a refuge from predation in aquatic communities. Oecologia 93:475486. https://doi.org/10.1007/BF00328954

Fernández HR, Domínguez E (2001) Guía para la determinación de los artrópodos bentónicos sudamericanos. Universidad Nacional de Tucumán, Tucumán

Ferreira A, Paula FR, Ferraz SFB, Gerhard P, Kashiwaqui EAL, Cyrino JEP, Martinelli LA (2012) Riparian coverage affects diets of characids in neotropical streams. Ecol Freshw Fish 21:12-22. https://doi.org/10.1111/j.1600-0633.2011.00518.x

Frehse FA, Braga RR, Nocera GA, Vitule JRS (2016) Non-native species and invasion biology in a megadiverse country: scientometric analysis and ecological interactions in Brazil. Biol Invasions 18:3713-3725. https://doi.org/10.1007 /s10530-016-1260-9

Galdean N, Callisto M, Barbosa FAR (2001) Biodiversity assessment of benthic macroinvertebrates in altitudinal lotic ecosystems of serra do cipó (MG, Brazil). Braz J Biol 61:239248. https://doi.org/10.1590/S0034-71082001000200006

Gomiero LM, Manzatto AG, Braga FMS (2008) The role of riverine forests for food supply for the omnivorous fish Brycon opalinus Cuvier, 1819 (Characidae) in the Serra do 
Mar, Southeast Brazil. Braz J Biol 68:321-328. https://doi. org/10.1590/S1519-69842008000200013

Gonçalves CS, Braga FMS (2012) Changes in ichthyofauna composition along a gradient from clearwaters to blackwaters in coastal streams of Atlantic forest (southeastern Brazil) in relation to environmental variables. Neotrop Ichthyol 10 : 675-684. https://doi.org/10.1590/S167962252012000300022

Gonçalves CS, Cestari C (2013) The use of an Atlantic Forest stream by the catfish Scleromystax barbatus (Quoy \& Gaimard, 1824). Neotrop Biol Conserv 8:115-120. https://doi.org/10.4013/nbc.2013.83.01

Gregory SV, Swanson FJ, McKee WA, Cummins KW (1991) An ecosystem perspective of riparian zones: focus on links between land and water. Bioscience 41:540-551. https://doi. org/10.2307/1311607

Hughes RM (1995) Defining acceptable biological status by comparing with reference conditions. In: Davis WS, Simon TP (eds) Biological assessment and criteria: tools for water resource planning and decision making. CRC Press Inc., Boca Raton

Ivlev VS (1961) Experimental ecology of the feeding of the fishes. University Press, New Haven

Kawaguchi W, Nakano S (2001) Contribution of terrestrial invertebrates to the annual resource budget for salmonids in forest and grassland reaches of a headwater stream. Freshw Biol 46: 3030-3316. https://doi.org/10.1046/j.13652427.2001.00667.x

Kawakami E, Vazzoler G (1980) Método gráfico e estimativa de índice alimentar aplicado no estudo de alimentação de peixes. Bol Inst Oceanogr 29:205-207. https://doi.org/10.1590 /S0373-55241980000200043

Kiffney PM, Richardson JS, Bull JP (2003) Responses of periphyton and insects to experimental manipulation of riparian buffer width along forest streams. J Appl Ecol 40:10601076. https://doi.org/10.1111/j.1365-2664.2003.00855.x

Legendre P, Legendre L (1998) Numerical ecology. Elsevier, Amsterdam

Leite GFM, Silva FTC, Gonçalves JF Jr, Salles P (2015) Effects of conservation status of the riparian vegetation on fish assemblage structure in neotropical headwater streams. Hydrobiologia 762:223-238. https://doi.org/10.1007 /s10750-015-2351-9

Lobón-Cerviá J, Mazzoni R, Rezende CF (2016) Effects of riparian forest removal on the trophic dynamics of a Neotropical stream fish assemblage. J Fish Biol 89:50-64. https://doi. org $/ 10.1111 / \mathrm{jfb} .12973$

Lorion CM, Kennedy BP (2009a) Relationships between deforestation, riparian forest buffers, and benthic macroinvertebrates in neotropical headwater streams. Freshw Biol 54:165-180. https://doi.org/10.1111/j.1365-2427.2008.02092.x

Lorion CM, Kennedy BP (2009b) Riparian forest buffers mitigate the effects of deforestation on fish assemblages in tropical headwater streams. Ecol Appl 19:468-479. https://doi. org/10.1890/08-0050.1

Mamede MCH, Cordeiro I, Rossi L, Melo MMRF, Oliveira RJ (2004) Mata Atlântica. In: Marques OAV, Duleba W (eds) Estação Ecológica Juréia-Itatins: ambiente físico, flora e fauna. Holos, Ribeirão Preto, pp 115-132
Manna LR, Rezende CF, Mazzoni R (2017) Effect of body size on microhabitat preferences in stream-dwelling fishes. J Appl Ichthyol 33:193-202. https://doi.org/10.1111/jai.13320

Marques OAV, Duleba W (2004) Estação Ecológica Juréia-Itatins: ambiente físico, flora e fauna. Holos, Ribeirão Preto

Menezes NA, Weitzman SH, Oyakawa OT, Lima FCT, Castro RMC, Weitzman MJ (2007) Peixes de água doce da Mata Atlântica: lista preliminar das espécies e comentários sobre a conservação de peixes de água doce Neotropicais. Museu de Zoologia da Universidade de São Paulo, São Paulo

Morton DC, DeFries RS, Shimabukuro YE, Anderson LO, Arai E, Espirito-Santo FB, Freitas R, Morisette J (2006) Cropland expansion changes deforestation dynamics in the southern Brazilian Amazon. P Natl Acad Sci USA 103:14637-14641. https://doi.org/10.1073/pnas.0606377103

Mugnai R, Nessimian JL, Baptista DF (2010) Manual de identificação de macroinvertebrados aquáticos do Estado do Rio de Janeiro. Technical Books, Rio de Janeiro

Murphy JF, Giller P (2000) Seasonal dynamics of macroinvertebrate assemblages in the benthos and associated with detritus packs in two low-order streams with different riparian vegetation. Freshw Biol 43:617-631. https://doi.org/10.1046 /j.1365-2427.2000.00548.x

Myers N, Mittermeier RA, Mittermeier CG, da Fonseca GAB, Kent J (2000) Biodiversity hotspots for conservation priorities. Nature 403:853-858. https://doi.org/10.1038/35002501

Naiman RJ, Décamps H (1997) The ecology of interfaces: riparian zones. Annu Rev Ecol Syst 28:621-658. https://doi. org/10.1146/annurev.ecolsys.28.1.621

Nakano S, Miyasaka H, Kuhara N (1999) Terrestrial-aquatic linkages: riparian arthropod inputs alter trophic cascades in a stream food web. Ecology 80:2435-2441. https://doi.org/ 10.1890/0012-9658(1999)080[2435:TALRAI]2.0.CO;2

Osborne LL, Kovacic DA (1993) Riparian vegetated buffer strips in water-quality restoration and stream management. Freshw Biol 29:243-258. https://doi.org/10.1111/j.1365-2427.1993. tb00761.x

Peressin A, Cetra M (2014) Responses of the ichthyofauna to urbanization in two urban areas in Southeast Brazil. Urban Ecosyst 17:675-690. https://doi.org/10.1007/s11252-0140352-5

Pinkas L, Oliphant MS, Iverson ILK (1971) Food habits of albacore, bluefin tuna and bonito in California waters. Calif Fish Game 152:1-105

Por FD (1986) Stream type diversity in the Atlantic lowland of the Juréia area (Subtropical Brazil). Hydrobiologia 131:39-45

Por FD (2004) Hidrobiologia da Juréia e da baixada do Ribeira rios e manguezais. In: Marques OAV, Duleba W (eds) Estação Ecológica Juréia-Itatins: ambiente físico, flora e fauna. Holos, Ribeirão Preto, pp 51-57

Por FD, Imperatriz-Fonseca VL (1984) The Juréia Ecological Reserve, São Paulo, Brazil - facts and plans. Environ Conserv 11:67-70. https://doi.org/10.1017 /S0376892900013515

Por FD, Lopes RM (1994) The streams of the Atlantic rainforest of Brazil. Verh Int Ver Theor Angew Limnol 25:1871-1875

Pusey BJ, Arthington AH (2003) Importance of the riparian zone to the conservation and management of freshwater fish: a review. Mar Freshw Res 54:1-16. https://doi.org/10.1071 /MF02041 
R Development Core Team (2014) R: a language and environment for statistical computing. R Foundation for Statistical Computing, Vienna http://www.R-project.org/

Rosemond AD, Pringle CM, Ramírez A, Paul MJ (2001) A test of top-down and bottom-up control in a detritus-based food web. Ecology 82:2279-2293. https://doi.org/10.1890/00129658(2001)082[2279:ATOTDA]2.0.CO;2

Sabino J, Castro RMC (1990) Alimentação, período de atividade e distribuição espacial dos peixes de um riacho da floresta Atlântica (sudeste do Brasil). Rev Bras Biol 50:23-36

Sabino J, Sazima I (1999) Association between fruit-eating fish and foraging monkeys in western Brazil. Ichthyol Explor Freshw 10:309-312

Sabino J, Silva CPD (2004) História natural de peixes da Estação Ecológica Juréia- Itatins. In: Marques OAV, Duleba W (eds) Estação Ecológica Juréia-Itatins: ambiente físico, flora e fauna. Holos, Ribeirão Preto, pp 230-242

Santos FB, Ferreira FC, Esteves KE (2015) Assessing the importance of the riparian zone for stream fish communities in a sugarcane dominated landscape (Piracicaba River Basin, Southeast Brazil). Environ Biol Fish 98:1895-1912. https://doi.org/10.1007/s10641-015-0406-4

Sazima I (1986) Similarities in feeding behaviour between some marine and freshwater fishes in two tropical communitits. J Fish Biol 29:53-65. https://doi.org/10.1111/j.10958649.1986.tb04926.x

Schlosser IJ (1991) Stream fish ecology: a landscape perspective. Bioscience 41:704-712

Schneider KN, Winemiller KO (2008) Structural complexity of woody debris patches influences fish and macroinvertebrate species richness in a temperate floodplain-river system. Hydrobiologia 610:235-244. https://doi.org/10.1007 /s10750-008-9438-5

Souza ALT, Fonseca DG, Libório RA, Tanaka MO (2013) Influence of riparian vegetation and forest structure on the water quality of rural low-order streams in SE Brazil. Forest Ecol Manag 298:12-18. https://doi.org/10.1016/j. foreco.2013.02.022

Sweeney BW, Newbold JD (2014) Streamside forest buffer width needed to protect stream water quality, habitat, and organisms: a literature review. J Am Water Resour As 50: 560-584. https://doi.org/10.1111/jawr.12203

Talora DC, Morellato PC (2000) Fenologia de espécies arbóreas em floresta de planície litorânea do sudeste do Brasil. Rev Bras Bot 23:13-26

Tarifa JR (2004) Unidades climáticas dos maciços litorâneos da Juréia-Itatins. In: Marques OAV, Duleba W (eds) Estação Ecológica Juréia-Itatins: ambiente físico, flora e fauna. Holos, Ribeirão Preto, pp 42-50

Teresa FB, Casatti L (2012) Influence of forest cover and mesohabitat types on functional and taxonomic diversity of fish communities in Neotropical lowland streams. Ecol Freshw Fish 21:433-442. https://doi.org/10.1111/j.16000633.2012.00562.x

Terra BF, Hughes RM, Araújo FG (2016) Fish assemblages in Atlantic Forest streams: the relative influenceof local and catchment environments on taxonomic and functional species. Ecol Freshw Fish 25:527-544. https://doi.org/10.1111 /eff. 1223

Triplehorn CA, Johnson NF (2011) Estudo dos insetos. Cengage Learning, São Paulo

Uieda VS, Pinto TLF (2011) Feeding selectivity of ichthyofauna in a tropical stream: space-time variations in trophic plasticity. Community Ecol 12:31-39. https://doi.org/10.1556 /ComEc.12.2011.1.5

Wantzen KM, Yule CM, Mathooko JM, Pringle CM (2008) Organic matter processing in tropical streams. In: Dudgeon D (ed) Tropical stream ecology. Academic Press, Amsterdan, pp 43-64

Wolff LL, Carniatto N, Hahn NS (2013) Longitudinal use of feeding resources and distribution of fish trophic guilds in a coastal Atlantic stream, southern Brazil. Neotrop Ichthyol 11: 375-386. https://doi.org/10.1590/S167962252013005000005

Wright JP, Flecker AS (2004) Deforesting the riverscape: the effects of wood on fish diversity in a Venezuelan piedmont stream. Biol Conserv 120:439-447. https://doi.org/10.1016/j. biocon.2004.02.022 